\title{
Forest Fires and Losses Caused by Fires - An Economic Approach
}

\author{
BEATA SADOWSKA \\ Department of Economics, Finance and Management \\ University of Szczecin \\ Mickiewicza 64, 71-101 Szczecin \\ beata.sadowska@usz.edu.pl \\ POLAND \\ ZIMON GRZEGORZ \\ Department of Finance, Banking and Accounting \\ Rzeszow University of Technology \\ Al. Powstancow Warszawy 12, Rzeszow 35-959 \\ POLAND \\ NINA STĘPNICKA \\ Department of Defence Studies \\ Jan Kochanowski University in Kielce \\ Branch in Piotrków Trybunalski \\ Słowackiego Street 114/118, Piotrków Trybunalski 97-300 \\ POLAND
}

\begin{abstract}
A defined forested area performs various functions such as economic, protective and social. Regardless of the level of civilization development and human knowledge, it cannot be stated that humans have full control over the phenomena occurring in forests or their surroundings. Forest hazards, including fire hazards, constitute a direct or indirect factor of human activity that has an effect on nature. Forest fires cause specific losses and generate costs, thus affecting a financial result. The research area of the study is forest fires and losses caused by them, i.e. determining the financial and non-financial effects of fires. The main aim of the study is to present the problem of forest fires in selected European countries, including Poland, and to determine the level of losses caused by them. The research hypothesis is: "Forest fires occurring in European countries, including Poland, cause significant losses in the natural and social environment, which forces organizations to incur costs of implementing measures to protect forest areas against fires". In the case of Poland, the area of interest is public forests managed by the State Forests National Forest Holding. The following research methods were used: critical analysis of the literature, comparative method, desk research, the method of induction and synthesis. In the field of empirical research, the current research results and studies of the Central Statistical Office and the reports of the State Forests were used.
\end{abstract}

Keywords: Fires, Forests, Economy, Costs

Received: September 12, 2020. Revised: February 16, 2021. Accepted: March 4, 2021.

Published: March 12, 2021.

\section{Introduction}

Fires are one of the main factors that have a destructive impact on the natural environment, causing long-term changes as well as disrupting life and development processes, leading to measurable or difficult to estimate losses, e.g. financial ones. 
They pose a serious threat to many countries around the world, from the Amazon through Asia, Africa to Siberia [1,2]. There are regions where their frequency is decreasing, but there are others where their increase is clearly visible, which is influenced by the climate change and the politics that destroy nature [3-7] From an economic and financial point of view, an assessment of the risk of major fires affecting local communities today becomes increasingly important in order to reduce potential losses in the future [8].

The actual amount of losses is an important element in the analysis of costs incurred to protect forests against fires. In Poland, expenses and costs related to forest protection are settled in cost accounting of the units of the State Forests National Forest Holding (PGL LP; LP) - regional directorates and forest divisions.

Forests are an essential factor in ecological balance. They provide biological productivity that has a market value. They are a common good that shapes the quality of human life. Fires are classified as factors negatively affecting the forest environment (the so-called stress factors), while the periodic intensification of at least one of the above-mentioned factors may lead to the collapse of biological resilience of forest ecosystems and catastrophic threats (local or regional) $[9,10]$. The primary cause of forest fires is human activity.

In Poland, accurate and complete statistical data concerns forest fires in the areas owned by the State Treasury that are managed by the State Forests. It concerns forest fires, taking into account forest spatial structure (distribution according to forest districts), time structure (time of formation and age of burned tree stands), origins, and losses caused by fires. Today, the forest area in Poland is over 9.2 million hectares, which corresponds to forest cover of $29.6 \%$.

The main aim of the study is to present the problem of forest fires in selected European countries, including Poland, and to determine the level of losses caused by them. The research hypothesis is: "Forest fires occurring in European countries, including Poland, cause significant losses in the natural and social environment, which forces organizations to incur costs of implementing measures to protect forest areas against fires". In the case of Poland, the area of interest is public forests managed by the State Forests National Forest Holding. The following research methods were used: critical analysis of the literature, comparative method, desk research, the method of induction and synthesis.

\section{Literature review}

Forests are multifunctional areas by nature. Sustainable forest management carried out in them is understood as activities aimed at shaping the structure of forests and their use in a manner and at a pace that ensures permanent preservation of their biological wealth, high productivity, viability and the ability to fulfil, now and in the future, all forest functions. The forest performs economic, social and environmental functions. The aim of the economic function is the production of wood raw material in order to meet the various needs of the society and the national economy. The aim of the environmental function is to fulfil climate, water protection, soil protection, recreational and health, as well as aesthetic and landscape tasks, whereas social function is to provide the public with the access to forests [11].

Forest fire hazard occurs from early spring to autumn. Depending on the meteorological conditions prevailing in a given year, it may reach its maximum intensity both in spring and summer months, and even at the beginning of autumn. It is influenced by the more and more frequent weather anomalies resulting from global climate changes, which cause fires in forests even in winter (with no snow cover)[12].

The report "Forest Fires in Europe, Middle East and North Africa 2017", published by the European Commission, shows that forest fires in the EU in 2017 affected more than 1.2 million ha and resulted in the death of 127 people. The estimates of losses caused by these fires in the European Forest Fire Information System amounted to approximately EUR 10 billion. In Poland, 
losses caused by fires in PGL LP amounted to PLN 1.3 million in 2017. Considering this fact, proper forest fire protection is of particular importance. According to the national reports of individual countries, Spain, Portugal and Poland recorded the highest number of fires among the EU countries in 2019 [13,14].

The effects of forest fires can be divided into economic and environmental. The economic effects include direct losses that take into account [15]:

- burned and damaged standing wood,

- burned and damaged sawn wood,

- burned or damaged production from minor forest products, which is understood by all collected nontimber forest products,

- costs of the firefighting action,

- cleaning up burned area,

- expenses for restoration of burned area.

Fires are an immense ecological disaster for the natural world. A forest fire has a negative impact on the atmosphere, tree stand, soil cover and the animal world.

Potential fire hazards in Poland are determined by the following factors[16]:

1. Abiotic:

- geographic location of Poland,

- climate (influence of maritime and continental climate),

- weather anomalies (extreme temperatures, precipitation, wind, droughts),

- soil (predominance of poor soils, high rainwater permeability).

2. Biotic:

- habitat-forest stand conditions (coniferous forest habitats, pine),

- age of stands (in Poland, stands 21-60 years old predominate, and stands of this age generate about $65 \%$ of all fires),

- health condition (insect pests, infectious diseases).
3. Anthropogenic - humans: industrial pollution (the impact of industrial emissions causes damage to stands and an increase in declining trees mass), tourist traffic, arson.

Forest fires in Poland are one of the main causes of losses in the forest environment. These losses determine changes in the stand, soil, undergrowth, fauna and flora. The result of forest fires are direct losses - damaged, destroyed stand and financial losses (wasted funds for forest cultivation and protection).

Other consequences of forest fires include:

1. Direct consequences (relating to forest management):

- raw material plus fire-fighting costs.

2. Indirect consequences (related to nonproductive functions of the forest and losses in the ecosystem):

- immeasurable losses in the ecosystem.

The consequences of forest fires and firerelated activities include, among others, involvement of human resources, the work of firefighters and foresters, and equipment. People lose health or life as a result of fires. There is also a reduction in biodiversity, disturbances in biogeochemical cycles - the amount of combustion products during a fire (carbon monoxide, carbon dioxide, cycloalkanes) and emissions to the atmosphere. The ecological effects are mainly the occurrence of acid rains, climate change, reduction of the number of game populations, reduction of the number of entomofauna, destruction and degradation, deterioration of the biological properties of the soil due to the destruction of the microflora, disruption of the humus formation process [17].

Fires must be prevented. It is a costeffective and efficient measure to reduce the effects of forest fires. Preventive actions not only reduce the costs of fire protection, but also contribute to limiting the damage. Information and warning activities are aimed at shaping appropriate behaviours in people, not creating a fire hazard in the forest and its surroundings. This activity should be one of 
the basic elements of nature and forest education conducted by PGL LP.

The issues of fires and losses caused by fires have been discussed by, inter alia: K. Adamowicz (2010); K. Adamowicz et al. (2016); W. Kusiak, R. Jaszczak (2015); K. Wiler, P. Wcisło (2013); R. Real, H.M. Vargas (1996); P. Walczykowski, A. Orych, J. Łysenko (2012); A.M.G. Lopez, M.G. Cruz, D. X. Viegas (2002); R. S. McAlpine (1989), M.M. Müller, H. Vacik, E. Valese (2015); J.G. Goldammer, N. Nikolov (2009) [18-26].

\section{Research Methodology}

The research area of the study is fires and losses caused by them, i.e. determining the financial and non-financial effects of fires. When investigating the research area, the authors asked themselves the following research questions:

1. What is the number of fires in forests and forest lands in selected European countries, including Poland?

2. What is the area of forest and forest land fires in selected European countries, including Poland?

3. What losses do fires cause in Poland?

4. What actions does PGL LP take to prevent fires?

5. What financial resources does PGL LP invest in fire protection, including measures to protect forest areas against fires in Poland?

The hypothesis made by the authors is as follows: Fires occurring in European countries, including Poland, cause significant losses in the natural environment and social environment, which in the case of Poland forces PGL LP to incur costs in connection with measures to protect forest areas against fires.

The main aim of the study is to present the problem of the occurrence of fires in selected European countries, including Poland, and to determine the level of losses caused by fires.

In order to verify the hypothesis and achieve the main goal, the following research methods and techniques were used: critical analysis of the literature on the subject, desk research method, comparative method, induction and synthesis method, techniques of graphical data presentation.

The limitation is the availability of data and the cost of obtaining it. But also the considerable diversity and spatial extent of forests in the world, Europe and Poland, including various forest management systems, which makes it difficult to compare the available studies.

The research process will be carried out in stages. Stage I includes preliminary research, identification of the research problem, its main goal, the studied population, as well as formulation of the research hypothesis. As part of this stage, a critical analysis of the literature on the subject, both Polish and foreign, as well as desk research analysis were performed. The publication of Statistics Poland entitled "Forestry" for the years 2014-2018 and financial and economic reports of the State Forests for the period 2014-2018 was used. Stage II concerns basic research. As part of this stage, empirical research was carried out on the number of forest and forest land fires in selected European countries, including Poland; the area of forest and land fires in hectares was indicated; the losses resulting from fires were classified; and the costs of fire protection (manufacturing costs) were disclosed. Empirical research also focused on potential fire hazards in Poland and the ecological role of fires. Stage III of the research process included conclusions and summary.

\section{The results of empirical research}

The authors' empirical research was preceded by an in-depth analysis of the phenomenon of fires and losses based on the information of the Global Forest Fire Information System (GWIS), the report on 2019 forest fires in Europe, the Middle East and North Africa, and European Forest Fire Information System data [27].

Forest fires occurring in all European countries are especially dangerous and frequent in the 
Mediterranean zone. Among the European Union countries, forest fires in Portugal, Spain, Italy, Sweden, France and Poland are particularly frequent and take place on large areas. The average number of fires in Portugal was 13923 fires in the period 2014-2018, while the average size of forest and land covered by fires in Portugal during this period amounted to 166045 ha. In Spain, the average number of fires in the analysed period was 10 290, and the average burned area was 83827 ha. In Italy, the average number of fires in the analysed years amounted to 5118 and on average it covered 84930 ha of forests and forest lands. In Poland, in 2014-2018, the average number of fires was 7049 , with the most frequent fire occurrences in 2015 and the least frequent in 2017. The average size of burned area in Poland is 2674 ha. Forest fires are the least frequent in Estonia - on average 75 fires a year; and in Slovenia - 72 fires. The smallest burned area was recorded in Estonia an average of 75 ha per year, and in Lithuania - 84 ha. The results covering the number of fires and forest land in selected European countries in 2014-2018 are presented in Table 1 , while Table 2 shows the area of forest and forest land fires in selected European countries in ha (2014-2018).

Table 1. Number of forest and forest land fires in selected European countries (20142018)

\begin{tabular}{|c|c|c|c|c|c|c|}
\hline $\begin{array}{l}\text { Coun } \\
\text { try }\end{array}$ & 2014 & 2015 & 2016 & 2017 & 2018 & $\begin{array}{l}\text { Aver } \\
\text { age } \\
\text { num } \\
\text { ber } \\
\text { of } \\
\text { fires }\end{array}$ \\
\hline $\begin{array}{l}\text { Austr } \\
\text { ia }\end{array}$ & 369 & 345 & 317 & 265 & 159 & 291 \\
\hline $\begin{array}{l}\text { Bulg } \\
\text { aria }\end{array}$ & 151 & 429 & 584 & 513 & 222 & 380 \\
\hline $\begin{array}{l}\text { Croat } \\
\text { ia }\end{array}$ & 43 & 177 & 151 & 329 & 54 & 151 \\
\hline $\begin{array}{l}\text { Cypr } \\
\text { us }\end{array}$ & 68 & 87 & 119 & 92 & 131 & 99 \\
\hline $\begin{array}{l}\text { Esto } \\
\text { nia }\end{array}$ & 91 & 67 & 84 & 61 & $n / d$ & 75 \\
\hline $\begin{array}{l}\text { Finla } \\
\text { nd }\end{array}$ & 1660 & 745 & 933 & 881 & 2427 & 1329 \\
\hline $\begin{array}{l}\text { Franc } \\
\text { e }\end{array}$ & 2778 & 4440 & 4285 & 4403 & 3005 & 3782 \\
\hline $\begin{array}{l}\text { Gree } \\
\text { ce }\end{array}$ & 552 & 510 & 777 & 1083 & 793 & 743 \\
\hline $\begin{array}{l}\text { Spai } \\
n\end{array}$ & 9771 & $\begin{array}{r}1192 \\
8\end{array}$ & 8817 & $\begin{array}{r}1379 \\
3\end{array}$ & 7143 & $\begin{array}{r}1029 \\
0\end{array}$ \\
\hline $\begin{array}{l}\text { Lithu } \\
\text { ania }\end{array}$ & 155 & 247 & 98 & 80 & 211 & 158 \\
\hline $\begin{array}{l}\text { Latvi } \\
\text { a }\end{array}$ & 698 & 704 & 641 & 423 & 972 & 688 \\
\hline $\begin{array}{l}\text { Ger } \\
\text { man } \\
y\end{array}$ & 429 & 1071 & 608 & 424 & 1708 & 848 \\
\hline $\begin{array}{l}\text { Nor } \\
\text { way }\end{array}$ & $\mathrm{n} / \mathrm{d}$ & 29 & 345 & 264 & 887 & 381 \\
\hline $\begin{array}{l}\text { POLA } \\
\text { ND }\end{array}$ & 5245 & $\begin{array}{r}1225 \\
7\end{array}$ & 5286 & 3592 & 8867 & 7049 \\
\hline $\begin{array}{l}\text { Port } \\
\text { ugal }\end{array}$ & 7067 & $\begin{array}{r}1585 \\
1\end{array}$ & $\begin{array}{r}1326 \\
1\end{array}$ & $\begin{array}{r}2100 \\
2\end{array}$ & $\begin{array}{r}1243 \\
6\end{array}$ & $\begin{array}{r}1392 \\
3\end{array}$ \\
\hline $\begin{array}{l}\text { Rom } \\
\text { ania }\end{array}$ & 83 & 250 & 174 & 447 & 158 & 222 \\
\hline $\begin{array}{l}\text { Slova } \\
\text { kia }\end{array}$ & 153 & 242 & 136 & 162 & 262 & 191 \\
\hline $\begin{array}{l}\text { Slove } \\
\text { nia }\end{array}$ & 35 & 93 & 90 & 108 & 32 & 72 \\
\hline $\begin{array}{l}\text { Switz } \\
\text { erlan } \\
\text { d }\end{array}$ & 56 & 166 & 81 & 110 & 153 & 113 \\
\hline $\begin{array}{l}\text { Swed } \\
\text { en }\end{array}$ & 4374 & 2700 & 5454 & 5276 & 8181 & 5197 \\
\hline $\begin{array}{l}\text { Turk } \\
\text { ey }\end{array}$ & $\mathrm{n} / \mathrm{d}$ & 2150 & 3188 & 2411 & 2167 & 1983 \\
\hline $\begin{array}{l}\text { Hung } \\
\text { ary }\end{array}$ & 1042 & 1069 & 452 & 1454 & 530 & 909 \\
\hline Italy & 3257 & 5442 & 5818 & 7855 & 3220 & 5118 \\
\hline
\end{tabular}

Table 2. Area of forest and forest land fires in selected European countries in ha (20142018) 


\begin{tabular}{|c|c|c|c|c|c|c|}
\hline Country & $\begin{array}{l}201 \\
4\end{array}$ & $\begin{array}{l}201 \\
5\end{array}$ & $\begin{array}{l}201 \\
6\end{array}$ & $\begin{array}{l}201 \\
7\end{array}$ & $\begin{array}{l}201 \\
8\end{array}$ & $\begin{array}{c}\text { Averag } \\
\text { e area } \\
\text { of fires }\end{array}$ \\
\hline Austria & 192 & 268 & 398 & 30 & 19 & 181 \\
\hline Bulgaria & 916 & $\begin{array}{r}431 \\
3\end{array}$ & $\begin{array}{r}634 \\
0\end{array}$ & $\begin{array}{r}456 \\
9\end{array}$ & $\begin{array}{r}145 \\
3\end{array}$ & 3518 \\
\hline Croatia & 188 & $\begin{array}{r}941 \\
6\end{array}$ & $\begin{array}{r}710 \\
0\end{array}$ & $\begin{array}{r}485 \\
43\end{array}$ & $\begin{array}{r}485 \\
43\end{array}$ & 22758 \\
\hline Cyprus & 669 & 652 & $\begin{array}{r}320 \\
5\end{array}$ & 428 & $\begin{array}{r}113 \\
6\end{array}$ & 1218 \\
\hline Estonia & 78 & 83 & 123 & 33 & $n / d$ & 75 \\
\hline Finland & 881 & 143 & 310 & 460 & $\begin{array}{r}122 \\
8\end{array}$ & 604 \\
\hline France & $\begin{array}{r}749 \\
3\end{array}$ & $\begin{array}{r}111 \\
60\end{array}$ & $\begin{array}{r}160 \\
93\end{array}$ & $\begin{array}{r}263 \\
78\end{array}$ & $\begin{array}{r}512 \\
4\end{array}$ & 13250 \\
\hline Greece & $\begin{array}{r}258 \\
46\end{array}$ & $\begin{array}{r}709 \\
6\end{array}$ & $\begin{array}{r}265 \\
40\end{array}$ & $\begin{array}{r}133 \\
93\end{array}$ & $\begin{array}{r}154 \\
64\end{array}$ & 17668 \\
\hline Spain & $\begin{array}{r}467 \\
21\end{array}$ & $\begin{array}{l}103 \\
200\end{array}$ & $\begin{array}{r}658 \\
17\end{array}$ & $\begin{array}{l}178 \\
234\end{array}$ & $\begin{array}{r}251 \\
62\end{array}$ & 83827 \\
\hline Lithuania & 162 & 71 & 26 & 53 & 110 & 84 \\
\hline Latvia & 591 & 615 & 467 & 265 & $\begin{array}{r}286 \\
4\end{array}$ & 960 \\
\hline Germany & 120 & 526 & 283 & 395 & $\begin{array}{r}234 \\
9\end{array}$ & 735 \\
\hline Norway & $n / d$ & 143 & $\begin{array}{r}188 \\
4\end{array}$ & 525 & $\begin{array}{r}327 \\
9\end{array}$ & 1457 \\
\hline POLAND & $\begin{array}{r}269 \\
0\end{array}$ & $\begin{array}{r}551 \\
0\end{array}$ & $\begin{array}{r}145 \\
1\end{array}$ & $\begin{array}{r}102 \\
3\end{array}$ & $\begin{array}{r}269 \\
6\end{array}$ & 2674 \\
\hline Portugal & $\begin{array}{r}199 \\
29\end{array}$ & $\begin{array}{r}644 \\
43\end{array}$ & $\begin{array}{l}161 \\
522\end{array}$ & $\begin{array}{l}540 \\
630\end{array}$ & $\begin{array}{r}437 \\
02\end{array}$ & 166045 \\
\hline Romania & 217 & $\begin{array}{r}167 \\
1\end{array}$ & 675 & $\begin{array}{r}245 \\
9\end{array}$ & $\begin{array}{r}134 \\
1\end{array}$ & 1273 \\
\hline Slovakia & 192 & 353 & 175 & 295 & 248 & 253 \\
\hline Slovenia & 18 & 65 & 526 & 441 & 20 & 214 \\
\hline Switzerlan & 45 & 47 & 454 & 118 & 69 & 147 \\
\hline Sweden & $\begin{array}{r}146 \\
66\end{array}$ & 594 & $\begin{array}{r}128 \\
8\end{array}$ & $\begin{array}{r}143 \\
3\end{array}$ & $\begin{array}{r}243 \\
10\end{array}$ & 8459 \\
\hline Turkey & $n / d$ & $\begin{array}{r}321 \\
9\end{array}$ & $\begin{array}{r}915 \\
6\end{array}$ & $\begin{array}{r}119 \\
93\end{array}$ & $\begin{array}{r}564 \\
4\end{array}$ & 7503 \\
\hline Hungary & $\begin{array}{r}445 \\
4\end{array}$ & $\begin{array}{r}473 \\
0\end{array}$ & 974 & $\begin{array}{r}493 \\
3\end{array}$ & 906 & 3199 \\
\hline Italy & $\begin{array}{r}361 \\
25\end{array}$ & $\begin{array}{r}415 \\
11\end{array}$ & $\begin{array}{r}479 \\
26\end{array}$ & $\begin{array}{l}137 \\
103\end{array}$ & $\begin{array}{l}161 \\
987\end{array}$ & 84930 \\
\hline
\end{tabular}

Source: own elaboration based on: Forestry. Statistics Poland. Warsaw 2018, 2019.[19]

Forest fire is an uncontrolled combustion process in the forest environment that causes environmental and material losses. As a result of forest fires, there occur losses directly and indirectly related to the destroyed or damaged stand. The indirect losses caused by fires sometimes exceed the direct losses many times over. Determining the size of fire losses in forests is difficult, but necessary to assess the economic effectiveness of the expenditures for fire prevention and putting them out. Stakeholders should be provided with information about the amount of losses, especially about lost non-productive functions of the forest. The methodology of calculating fire losses in forests is specified in the Regulation of the Minister of the Environment of June 20, 2002, on one-off compensation for premature felling of forest stands (Journal of Laws No. 99, item 905). This method, like all the previous ones, does not take into account the losses related to the limitation (loss) of non-productive functions of the forest, losses occurring on the edges of the fire, as well as losses resulting from greenhouse gas emissions and reduction of the carbon dioxide absorption area [28].

The value of losses due to forest fires in Poland in million PLN (estimated values) is presented in Table 3.

\section{Table 3. Value of losses due to forest fires in PLN million (estimated values)}

\begin{tabular}{lccccc}
\hline \multicolumn{1}{c}{ Item } & 2014 & 2015 & 2016 & 2017 & 2018 \\
& & & & & \\
\hline $\begin{array}{l}\text { Value of forest } \\
\text { fire losses }\end{array}$ & 4.0 & 6.6 & 1.8 & 1.3 & 4.8 \\
& & & & & \\
\hline $\begin{array}{l}\text { Source: own elaboration based on: Forestry. Statistics } \\
\text { Poland. Warsaw 2018, } 2019\end{array}$ [19,20] & & &
\end{tabular}

The economic value of losses due to fires in Poland varied in the analysed years, with the highest values recorded in 2015 PLN 6.6 million, and the lowest in 2017 PLN 1.3 million. 2018 year witnessed a growing trend - PLN 4.8 million. Fire losses are determined on the basis of:

- the regulation regarding the lost value of stands due to premature felling mentioned in the introduction,

- invoices, bills, payrolls of legal and natural persons involved by the person in charge of rescue operations when extinguishing a fire and by the owner (manager) of the forest during its extinguishing and supervision.

The amount of losses for premature (complete) felling is calculated from the formula: 


$$
\mathrm{O}=(\mathrm{Wi}-\mathrm{Ws}) \times \mathrm{Z} \times \mathrm{P} \times \mathrm{C}
$$

If the value of $\mathrm{W}_{\mathrm{s}}$ has been determined, the amount of losses is determined according to the following formula:

$$
\mathrm{O}=\mathrm{Wk} \times \mathrm{Z} \times \mathrm{P} \times \mathrm{C}
$$

where:

$\mathrm{O}$ - loss value in PLN,

$\mathrm{Wi}$ - index of the expected value of 1 ha of standing wood at the troughfell age,

Ws - index of the value of 1 ha of standing wood at the early felling age of this stand,

Wk - index of the value of costs incurred for establishing and maintaining 1 ha of a stand,

$\mathrm{Z}$ - the stocking level of stands, which is the quotient of the actual volume of tree stands at the early felling age and the volume potentially achievable by this stand,

$\mathrm{P}$ - stand area (burned), in ha,

$\mathrm{C}$ - the current selling price of $1 \mathrm{~m} 3$ of wood specified in the announcement by the President of Statistics Poland, published in the Official Journal of the Republic of Poland, "Monitor Polski", for forest tax purposes.

Fires are one of the most dangerous natural disasters as they cause permanent ecological changes in forests. Fire in a forest results in numerous losses, and its negative consequences in the natural environment are removed for many years. PGL LP conducts numerous activities aimed at reducing the risk of fire in forest areas [30-32].

As part of forest protection, fire protection was also carried out using traditional methods and in the form of aerial patrolling and extinguishing of forest fires. There is a network of meteorological measurement points in LP, used to forecast forest fire risk. It consists of 60 prognostic points and 87 auxiliary measurement points. The above points are evenly distributed across 60 forecast zones. The cost of their maintenance includes the costs of transmission of measurement data, periodic inspections, technical service and maintenance of the reporting point, modernization and maintenance of the application for collecting, verifying and presenting measurement data from the network of meteorological measurement points [31]
In terms of protection of property against fires, the State Forests cooperate with many organizations and institutions, including, in particular, the State Fire Service (PSP) and Volunteer Fire Brigades (OSP). Organizational units of the State Forests, to the best of their ability and in justified cases, donated a part of the achieved financial result for socially useful purposes, including public and educational units. In the years 2014-2018, financial support was provided to PSP and OSP units, and the level of this support is shown in Figure 1 .

\section{Figure 1. The level of financial support for units of the State Fire Service and \\ Volunteer Fire Service in Poland as part of forest fire protection tasks (2015-2018) in thousand PLN.}

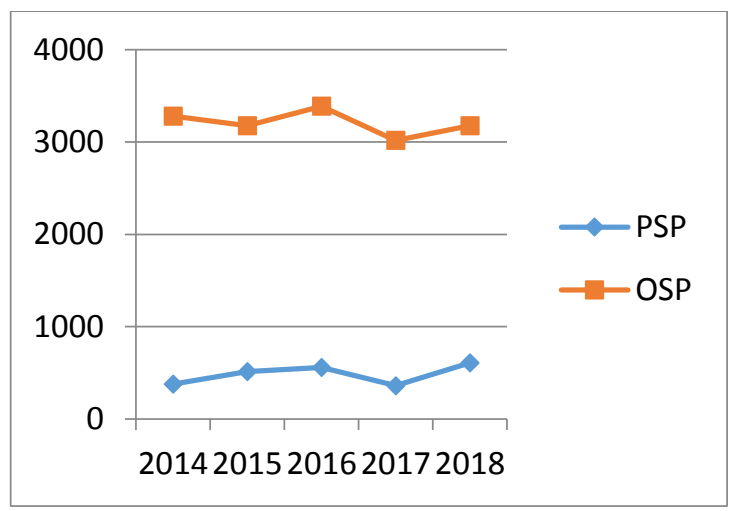

Source: own elaboration based on financial and economic reports of PGL LP for 20142018 https://www.lasy.gov.pl [retrieved: 30.11.2020].

PSP received the highest financial support from the State Forests in 2015, in the amount of PLN 608 thousand, while the lowest was PLN 362 thousand in 2016. PGL LP allocated financial resources in the amount of PLN 3387 to perform tasks in the field of fire protection to OSP in 2017.

Costs of forest fire protection in thousand PLN in the analysed period, incurred by PGL LP, are presented in Table 4 and Figure 2.

Table 4. Costs of forest fire protection and general costs of State Forests in thousand PLN 


\begin{tabular}{|c|c|c|c|c|c|}
\hline Item & 2014 & 2015 & $\begin{array}{c}201 \\
6\end{array}$ & $\begin{array}{c}201 \\
7\end{array}$ & 2018 \\
\hline $\begin{array}{l}\text { Fire protection } \\
\text { (manufacturin } \\
\text { g costs) } \\
\text { including } \\
\text { measures to } \\
\text { protect forest } \\
\text { areas against } \\
\text { fire (direct } \\
\text { costs) }\end{array}$ & $\begin{array}{r}86 \\
515\end{array}$ & $\begin{array}{r}94 \\
384\end{array}$ & $\begin{array}{l}255 \\
936\end{array}$ & $\begin{array}{r}24 \\
203\end{array}$ & $\begin{array}{r}25 \\
772\end{array}$ \\
\hline $\begin{array}{l}\text { Total costs of } \\
\text { the State } \\
\text { Forests }\end{array}$ & $\begin{array}{r}756 \\
8 \\
443\end{array}$ & $\begin{array}{r}778 \\
6 \\
112\end{array}$ & $\begin{array}{r}7 \\
985 \\
846\end{array}$ & $\begin{array}{r}8 \\
519 \\
509\end{array}$ & $\begin{array}{r}923 \\
6 \\
132\end{array}$ \\
\hline
\end{tabular}

Source: own elaboration based on: Forestry.

Statistics Poland. Warsaw 2018, 2019 [29].

Figure 2. Costs of forest fire protection in thousand PLN in relation to the general costs of LP (manufacturing costs, direct)

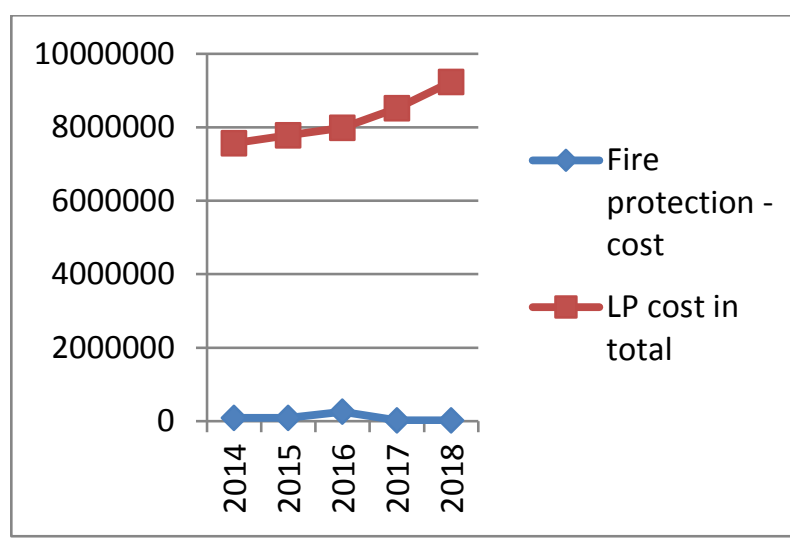

Source: own elaboration based on: Forestry. Statistics Poland. Warsaw 2018, 2019 [29].

The highest costs of fire protection were recorded by PGL LP in 2016. Fire protection costs include many cost items and expenditures related to [32]:

- monitoring of bedding moisture,

- construction of fire towers (observation towers),

- ranger's alert and disposition posts (PAD),

- operation of patrol and firefighting vehicles,

- maintenance of water access points,

- maintenance of roads and fire department access roads,

- purchase of modern equipment enabling the location and detection of fires,
- building own meteorological stations.

\section{Conclusions and discussion}

The research area of the study was forest fires and losses caused by fires, i.e. determining the financial and non-financial effects of fires. The main aim of the study was to present the problem of forest fires in selected European countries, including Poland, and to determine the level of losses caused by fires. This issue is present both in the literature on the subject and in economic practice.

The authors' own empirical research was preceded by an in-depth analysis of the phenomenon of fires and losses due to this, based on the information of the Global Forest Fire Information System (GWIS), reports on 2019 forest fires in Europe, the Middle East and North Africa, and European Forest Fire Information System data. The purpose of this was to compare information about fires and losses and to assess the state of development of this phenomenon both in time and space.

It should be emphasized that the source of data on the number of fires, losses due to fires and costs of forest protection against fires are the statements published in public statistics and in the reports of PGL LP. Regardless of the size of the fire, it should be recognized that all fire causes losses. Forest fires are a common threat that lead to large social, economic and environmental losses. Socio-economic development results in an increased human impact on forest environments and a growth in the number of fires, which translates into an increase in natural and non-natural losses, mainly material ones. To minimize losses, PGL LP incurs the costs of fire protection. These costs are recorded in the financial systems of the PGL LP units. The considerations in the article lead to the following conclusions:

1. The number of forest and forest land fires in selected European countries, including Poland, is at different levels in the analysed years and is conditioned by various factors.

2. The area of the fires is also diversified.

3. Fires cause significant losses directly and indirectly related to the destroyed 
or damaged stand. These losses determine changes not only in the stand, but also in the entire ecosystem: in soil, undergrowth, fauna and flora.

4. PGL LP undertakes actions to counteract fires, such as: construction and modernization of ground-level fire towers equipped with TV cameras, purchase of patrol cars equipped with extinguishing modules, purchase and retrofitting of patrol planes, purchase of radiotelephones and construction of fire hydrants.

5. PGL LP invest its financial resources in fire protection, including measures to protect forest areas against fires in Poland. The average annual costs of forest protection (production costs) in the analysed period amounted to PLN 97 000. In the last two analysed years, they were at a lower level, i.e. PLN 25 000 .

The conducted research allowed to positively verify the hypothesis put forward in the introduction that: Fires occurring in European countries, including Poland, cause significant losses in the natural environment and social environment, which in the case of Poland forces PGL LP to incur costs in connection with measures to protect forest areas against fires.

The results of the research conducted allow for the formulation of recommendations. It is recommended (1) to increase expenditure on fire protection, primarily in the field of installing new fire - fighting belts $(\mathrm{km})$, setting up new observation and alarm contact points, increasing the number of ground patrols and water drawing points, investing in the purchase of new cars and airplanes used in forest fire protection activities. It should be emphasized that fires are most often caused by humans, therefore it is also recommended to (2) increase expenditure on training and educational activities, cooperate with the mass media on a macro scale, carry out information measures at all levels of education for children and adolescents. It is also postulated that PGL
LP should disclose indirect costs related to forest fire protection, as the information reported in financial and economic reports and in the publication "Forestry" of Statistics Poland reflects only a part of these costs, i.e. production costs (direct costs). The society should be made aware of the fact that the costs of forest protection are significant and that the financial resources involved in this area of PGL LP's activity could be spent on basic activities, for example new plantings. The key issue here is broadly understood human awareness, created through education and access to complete information.

The above conclusions are general in nature and constitute a contribution to further in-depth scientific research in the field of forest fires and losses caused by them.

\section{References}

[1] Milanović, S.; Marković, N.; Pamučar, D.; Gigović, L.; Kostić, P.; Milanović, S.D. Forest Fire Probability Mapping in Eastern Serbia: 2021. Logistic Regression versus Random Forest Method. Forests 2021, 12, 5. https://doi.org/10.3390/f12010005

[2] Doerr, S.H.; Santín, C. 2016. Global trends in wildfire and its impacts: Perceptions versus realities in a changing world.Philos. Trans. R.Soc. Lond. B Biol. Sci.2016,371, 20150345.

[3] Flannigan, M.D.; Krawchuk, M.A.; de Groot, W.J.; Wotton, B.M.; Gowman, L.M. 2009. Implications of changing climate for global wildland fire.Int. J. Wildl. Fire2009,18, 483-507.

[4] Flannigan, M.; Cantin, A.S.; de Groot, W.J.; Wotton, M.; Newbery, A.; Gowman, L.M. 2013. Global wildland fire season severity in the21st century. Ecol. Manag.2013,294, 54-61.

[5] Moritz, M.A.; Batllori, E.; Bradstock, R.A.; Gill, A.M.; Handmer, J.; Hessburg, P.F.; Leonard, J.; McCaffrey, S.; Odion, D.C.;Schoennagel, T.; et al. 2014.

Learning to coexist with wildfire.Nature2014,515, 58-66. 
[6] Turco, M.; Rosa-Cánovas, J.J.; Bedia, J.; Jerez, S.; Montávez, J.P.; Llasat, M.C.; Provenzale, A. 2018. Exacerbated fires in Mediterranean Europe due to anthropogenic warming projected with non-stationary climate-fire models.Nat. Commun.2018,9, 1-9.

[7] Feurdean, A.; Vannière, B.; Finsinger, W.; Warren, D.; Connor, S.C.; Forrest, M.; Liakka, J.; Panait, A.; Werner, C.; Andri c, M.;et al. 2020. Fire hazard modulation by long-term dynamics in land cover and dominant forest type in eastern and central Europe.Biogeosciences2020,17, 1213-1230.

[8] Oliveira, S.; Gonçalves, A.; Benali, A.; Sá, A.; Zêzere, J.L.; Pereira, J.M. 2020. Assessing Risk and Prioritizing Safety Interventions in Human Settlements Affected by Large Wildfires. Forests 2020, 11,859 .

https://doi.org/10.3390/f11080859

[9] Report on the condition of forests in Poland in 2016. the State Forests National Forest Holding. Warsaw 2017, p. 10;

[10] A. Prędecka: Fire in the forest and nature. Methodological manual with lesson plans for representatives of the Volunteer Fire Brigades, General Directorate of State Forests, Warsaw 2011, pp. 6-9.

[11] Grzywacz A. (2016): Forest real estate valuation. Educaterra. Olsztyn 2016.

[12] Instruction of forest fire protection.(2020) State Forests Information Center. Warsaw 2020.

[13] Fire safety of state forests. Supreme Chamber of Control. Warsaw 2019, p. 5. https://www.nik.gov.pl [retrieved: 27.11.2020];

[14] Forest fires threaten Europe, https://ec.europa.eu [retrieved: 27.11.2020]; Annual fire reports, https://effis.jrc.ec.europa.eu/reports-andpublications/annual-fire-reports [retrieved: 28.11.2020].
[15] Fire situation in Poland. https://www.ibles.pl [retrieved: 28.11.2020].

[16] A. Perlińska, R. Szczygieł: The risk and consequences of forest fires. https://www.ibles.pl, [retrieved: 29.11.2020].

[17] Adamowicz K (2010).: An attempt to determine the impact of changes in the scope of fire protection in forests on the number and size of fires in 2000-2008. Zarządzanie Ochroną Przyrody w Lasach, 2010.

[18] Adamowicz K., et al. (2016): Financial determination of the size of losses on the average growth of stands damaged by a hurricane. Acta Scientiarum Polonorum. Silvarum Colendarum Ratio et Industria Lignaria, 2016, 15.3.

[19] Goldammer J.G., Nikolov N. (2009): Climate change and forest fires risk. Proceedings of the European and Mediterranean Workshop, Climate change impact on water-related and marine risks, Murcia (Spain), 26-27 October, 2009.

[20] Kusiak W., Jaszczak R. (2015): Introduction to forestry. Wydawnictwo Uniwersytetu Przyrodniczego w Poznaniu, Poznań 2015.

[21] Lopes A.M.G., Cruz M.G., Viegas D.I (2002).: FireSsation - an integrated software system for the numerical simulation of fire spread on complex topography. Environmental Modelling and Software, 2002, 17.

[22] McAlpine R.S. (1989): Temporal variations in elliptical forest fire shapes. Canadian Journal Research, 1989, 19.

[23] Müller M.M., Vacik H., Valese E. (2015): Anomalies of the Austrian forest fire regime in comparison with other Alpine countries: a research note, "Forests" 2015, 6(4), pp 44-52.

[24] Real R. , Vargas H.M. (1996): The Probabilistic Basis of Jaccard's Index of Similarity. Systematic Biology 45(3), 
1996, pp. 380-385. DOI 10.1093/sysbio/45.3.380.

[25] Walczykowski P., Orych A., Łysenko J.(2012): An example of using Landsat TM images to assess the state of forest fire risk. Archiwum Fotogrametrii, Kartografii i Teledetekcji 24. Warsaw 2012.

[26] Wiler K., Wcisło P. (2013): Protection of forests against fires State Forests Information Center. Warsaw 2013.

[27]https://ec.europa.eu, [dostęp: 20.11.2020r.].

[28] Forestry. Statistics Poland 2014-2018. Warsaw. www://stat.gov.pl [retrieved: 26.11.2020].

[29] Financial and economic reports for the years 2014-2018. State Forests National Forest Holding. Warsaw. https://www.lasy.gov.pl [retrieved: 27 Index of Similarity. Systematic Biology 45(3), 1996, pp. 380-385.

[30] Kozuch, A; M. Piszczek, G. Stanczak, (2015): Costs of fire prevention and fire fighting in the Regional Directorate of State Forests in Katowice. Zarządzanie Ochroną Przyrody w Lasach, 2015, p. 9.

[31] Financial and economic report of PGL LP for 2015-2018, https://www.lasy.gov.pl [retrieved: 30.11.2020

[32] https://swiatoze.pl [retrieved: 29.11.2020]

\section{Contribution of individual authors to the creation of a scientific article (ghostwriting policy)}

\section{Author Contributions:}

Beata Sadowska, - responsible for organizing and conducting the study, systematizing data, reviewing the literature, developing content, analysis, statistics, systematizing data, content development.

Grzegorz Zimon, Nina Stępnicka -responsible for reviewing the literature, developing content, analysis, statistics, systematizing data.

\section{Creative Commons Attribution License 4.0 (Attribution 4.0 International, CC BY 4.0)}

This article is published under the terms of the Creative Commons Attribution License 4.0 https://creativecommons.org/licenses/by/4.0/de ed.en_US 